\title{
Status of faecal pollution in ports: A basin-wide investigation in the Adriatic Sea
}

\author{
Gian Marco Luna ${ }^{\mathrm{a}, *}$, Elena Manini ${ }^{\mathrm{a}}$, Valentina Turk ${ }^{\mathrm{b}}$, Tinkara Tinta ${ }^{\mathrm{b}}$, Giuseppe D'Errico ${ }^{\mathrm{c}}$, Elisa Baldrighi ${ }^{\mathrm{a}}$, \\ Vanja Baljak ${ }^{\mathrm{d}}$, Donatella Buda ${ }^{\mathrm{e}}$, Marina Cabrini ${ }^{\mathrm{f}}$, Alessandra Campanelli ${ }^{\mathrm{a}}$, Arijana Cenov ${ }^{\mathrm{g}}$, Paola Del Negrof, \\ Dragana Drakulovićh ${ }^{\text {, Cinzia Fabbrof }}$, Marin Gladg, Dolores Grilec ${ }^{\mathrm{i}}$, Federica Grillia ${ }^{\mathrm{a}}$, Sandra Jokanović ${ }^{\mathrm{h}}$, \\ Slaven Jozićj, Vesna Kauzlarićck, Romina Kraus ${ }^{1}$, Mauro Marini ${ }^{\mathrm{a}}$, Josip Mikušm ${ }^{\mathrm{m}}$, Stefania Milandrie, \\ Marijana Pećarevićm ${ }^{\text {, Laura Perini }}{ }^{n}$, Grazia Marina Quero ${ }^{\circ}$, Mladen Šolićj, Darija Vukić Lušićd, g, Silvia Zoffoli \\ a Institute of Marine Sciences (CNR-ISMAR), National Research Council, Largo Fiera della Pesca 2, Ancona, Italy \\ ${ }^{\mathrm{b}}$ National Institute of Biology, Marine Biology Station, Fornače 41, Piran, Slovenia \\ ${ }^{c}$ Department for Life and Environmental Science (DISVA), Polytechnic University of Marche, Ancona, Italy \\ ${ }^{\mathrm{d}}$ University of Rijeka, Faculty of Medicine, Department of Environmental Health, Braće Branchetta 20, Rijeka, Croatia \\ ${ }^{\mathrm{e}}$ Fondazione Centro Ricerche Marine, Laboratorio Nazionale di Riferimento per le Biotossine Marine, Viale A. Vespucci 2, Cesenatico, FC, Italy \\ ${ }^{\mathrm{f}}$ OGS (Istituto Nazionale di Oceanografia e di Geofisica Sperimentale), Oceanography Division, via A. Piccard 54, Trieste, Italy \\ ${ }^{g}$ Teaching Institute of Public Health of Primorje-Gorski Kotar County, Department of Environmental Health, Krešimirova 52a, Rijeka, Croatia \\ ${ }^{\mathrm{h}}$ Institute of Marine Biology, Kotor, Montenegro \\ ${ }^{\mathrm{i}}$ Institute of Public Health of Dubrovnik-Neretva County, Croatia \\ ${ }^{\mathrm{j}}$ Institute of Oceanography and Fisheries, Split, Croatia \\ ${ }^{\mathrm{k}}$ Institute of Public Health of Istrian County, Department of Environmental Health, Pula, Croatia \\ ${ }^{1}$ Ruđer Bošković Institute, Center for Marine Research, Giordano Paliaga 5, Rovinj, Croatia \\ ${ }^{\mathrm{m}}$ University of Dubrovnik, Department of Aquaculture, Ćira Carića 4, Dubrovnik, Croatia \\ ${ }^{\mathrm{n}}$ University of Ljubljana, Ljubljana, Slovenia \\ ${ }^{\circ}$ Stazione Zoologica Anton Dohrn, Villa Comunale, Napoli, Italy
}

\section{ART ICLE INFO}

Keywords:

Faecal bacteria

Ports

qPCR

Adriatic Sea

\begin{abstract}
A B S T R A C T
Ports are subject to a variety of anthropogenic impacts, and there is mounting evidence of faecal contamination through several routes. Yet, little is known about pollution in ports by faecal indicator bacteria (FIB). FIB spatio-temporal dynamics were assessed in 12 ports of the Adriatic Sea, a semi-enclosed basin under strong anthropogenic pressure, and their relationships with environmental variables were explored to gain insight into pollution sources. FIB were abundant in ports, often more so than in adjacent areas; their abundance patterns were related to salinity, oxygen, and nutrient levels. In addition, a molecular method, quantitative (q)PCR, was used to quantify FIB. qPCR enabled faster FIB determination and water quality monitoring that culture-based methods. These data provide robust baseline evidence of faecal contamination in ports and can be used to improve the management of routine port activities (dredging and ballast water exchange), having potential to spread pathogens in the sea.
\end{abstract}

\section{Introduction}

Faecal pollution of the coastal ocean impairs water quality and poses a worldwide health threat by promoting the spread of infectious diseases among humans and marine organisms (Shuval, 2003; McLellan and Eren, 2014). A variety of point and non-point pathways and sources - especially sewer overflows, drainage of storm water, runoff from farmed and urban areas, leaking septic systems and sewerage lines, discharges from craft, and atmospheric deposition of aerosols - can result in contamination of coastal waters with faecal bacteria (Oliver et al., 2016a; Newton et al., 2013; Stewart et al., 2008). Monitoring faecal pollution is essential to understand the fate of microbes, and to identify the reservoirs and hotspots that promote the spread of faecal bacteria across the coastal ocean, with a view to preventing or mitigating their spread to the coastal ocean.

\footnotetext{
* Corresponding author.

Email address: gianmarco.luna@ve.ismar.cnr.it (G.M. Luna)
} 
The intense shipping traffic and industrial activities that take place in ports and harbours make them typical chemical pollution hotspots (Ghosh et al., 2003; Lin et al., 2013) and sites with potentially high microbial contamination. Most previous investigations in such areas have focused on chemical contamination (Renzi et al., 2009), whereas systematic studies to quantify and measure microbial pollution in ports and harbours are not available. Recent investigations have only sporadically involved sampling of water (Dheenan et al., 2016) or sediments (Wong et al., 1995; Luna et al., 2012) inside large ports, and have reported typically high abundances of bacteria of faecal origin. Their concentrations in seawater have been reported to be higher near harbours than in coastal areas immediately outside them (Dheenan et al., 2016), while high levels of coprostanol, an indicator of sewage pollution, have been measured in sediments collected from a large industrial port (Jeng and Han, 1994). A recent study of Italian ports -small ports, large ports hosting international traffic as well as coastal areas - has found that faecal pollution was highest in the larger ports (Chiaretti et al., 2014).

A wide range of activities that take place in ports are also likely to affect dynamics and fate of faecal bacteria. Notably, routine sediment dredging and related activities (e.g. placement of dredge material to ensure access to the port; Casado-Martínez et al., 2006) induce resuspension that may disseminate the faecal pathogens stored in sediment (Luna et al., 2012; Amalfitano et al., 2015). Ballast water (BW) exchanges - which according to the Ballast Water Management Convention (International Maritime Organization, 2004) should be conducted in the open ocean to purge ballast tanks of pathogens and other organisms acquired with BW uptake in ports and coastal waters - are also likely to influence bacterial dynamics in ports and nearby areas. The above considerations as well as the increasing coastal urbanization and the growing shipping traffic, due to the globalization of manufacturing processes and the rise of global-scale trade (Viana et al., 2014), stress the importance of assess the magnitude and trends of faecal contamination in port areas, to ensure that these sites and adjacent areas are appropriately managed.

Throughout the world, coastal water quality is monitored for faecal pollution using faecal indicator bacteria (FIB), of which the most widely used are Escherichia coli (EC) and enterococci (ENT) (Field and Samadpour, 2007). In the EU, the provisions regulating bathing water quality involve monitoring of EC and ENT (Bathing Water Directive, BWD, 2006/7/EC). Their enumeration is commonly performed by culture-based methods, which are time-consuming ( $>24 \mathrm{~h}$ from sampling to results) and, given the limited culturability of bacteria from environmental samples (Staley and Konopka, 1985), have the potential to bias results, thus hampering the use of these approaches for health risk monitoring (Haugland et al., 2005; Oliver et al., 2014). Recent technological advances have led to the development of faster molecular methods to quantify bacteria, including FIB, in food and environmental samples (Law et al., 2015). Quantitative PCR (qPCR) assays targeting gene sequences specific for FIB have attracted great interest and have been proposed as possible alternatives to culture-based methods for water quality assessment (Oliver et al., 2016a). Although a number of studies have assessed the value of qPCR in monitoring recreational water quality (Noble and Weisberg, 2005; Converse et al., 2012; Haugland et al., 2016), little work has been conducted on water and sediment quality in ports (Luna et al., 2012), where faecal pollution is expected to be high and where routine operations, such as dredging and BW exchanges, require fast monitoring methods enabling rapid issue of health warnings.

In this study a simultaneous, multi-site investigation was conducted to detect and quantify FIB in seawater and sediments in 12 ports and adjacent urbanized coastal areas throughout the whole Adriatic Sea (Mediterranean Sea), a semi-enclosed basin subject to strong anthropogenic pressure. The study involved seasonal sampling (all four seasons) in different meteorological and hydrological conditions to measure the levels of faecal pollution and its spatio-temporal variability and to identify their potential relationships with the main environmental variables. A novel, rapid qPCR approach was also tested in one selected port, to establish whether it can provide an alternative to the culture-based methods currently used to quantify FIB abundance.

\section{Materials and methods}

\subsection{Sampling areas and activities}

Sampling was performed in 12 large commercial ports, selected throughout the Adriatic Sea (Fig. 1), which differed mainly in the amount of shipping traffic hosted and the BW volume discharged (Table 1). Sampling was conducted in spring (March-May 2014 or 2015, depending on the port), summer (June-September 2014), autumn (October-November 2014), and winter (January-March 2015). The sampling stations in each port and adjacent urbanized areas ranged from 3 (Šibenik) to 9 (Ancona and Venice). The location, geographical coordinates, and characteristics of the sampling stations established in each port are listed in detail in Kraus et al. (a) (under review in the same Special Issue). Sampling for microbiological analyses was carried out at stations established in and outside the port. In Italy, samples were collected in Bari, Ancona, Venice, and Trieste as follows: Bari, 6 stations, 3 inside (BIbw1, BIbw2 and BIbw3) and 3 outside the port (BIref4, BIref5 and BIref8); Ancona, 9 stations, 4 inside (ANbwDS, ANbwLR, BALMan and BALPort) and 5 outside (ANancAPI, ANrefSL1, ANrefSL2, ANancMB and BALblk); Venice, 9 stations, 4 inside (VEbwIN, VEbwW2, VEbwW3 and VEbwP1) and 5 outside (VEbw7M, VErefW4, VErefS1, VErefS2 and VEancPTF); Trieste, 7 stations, 5 inside (TSbw1, TSbw2, TSbw3, TSbw4 and TSbwM) and 2 outside (TSchm7 and TSrefC1). In Slovenia sampling was performed in the port of Koper at 4 stations, 3 inside (KObw1, KObw2 and KObw3) and one outside the port (KOanc4). In Croatia samples were collected in the ports of Pula, Rijeka, Šibenik, Split, and Ploče as follows: Pula, 4 stations, 3 inside (PUbwC, PUbwS and PUchm) and one outside (PUref); Rijeka, 4 stations, 3 inside (RIchm, RIbwB and RIbwS) and one outside (RIref); Šibenik, 3 stations, 2 inside (SIbw1 and SIbw2) and one outside (SIbw3); Split, 4 stations, 3 inside (STbwL1, STbwL2 and STbwK1) and one outside the port, fairly close to the open sea (STbwJ1); in Ploče, 4 stations were sampled inside the port (PLbw1, PLbw3, PLbw5 and PLbwKV) only in spring (May 2016). In Montenegro sampling in the port of Bar was performed at 4 stations, 3 inside (BAbw1, BAbw2 and BAibw3) and one outside (BAref). In Albania, sampling in the port of Durres involved 4 stations, 3 inside (DUbw1, DUbw2 and DUbw3) and one outside the port (DUref6).

For FIB determinations, samples of surface seawater were collected in each port using either sterile containers (capacity 11) or a Niskin bottle (capacity 5-121). Sediment samples were collected using a box-corer or a Van Veen grab sampler. After collection, the surface layer $(0-2 \mathrm{~cm})$ of sediment was transferred aseptically to sterile tubes $(50-100 \mathrm{ml}, 3$ replicates). Sampling operations were carried out on board research boats. Immediately after collection, samples were transported to the laboratory at in situ temperature in the dark and processed within a few hours of collection. For seawater nutrient analysis, seawater samples were filtered (Whatman GF/F) and stored at $-20^{\circ} \mathrm{C}$ until use, see Kraus et al. (b) (under review in the same Special Issue) for a more detailed description. 


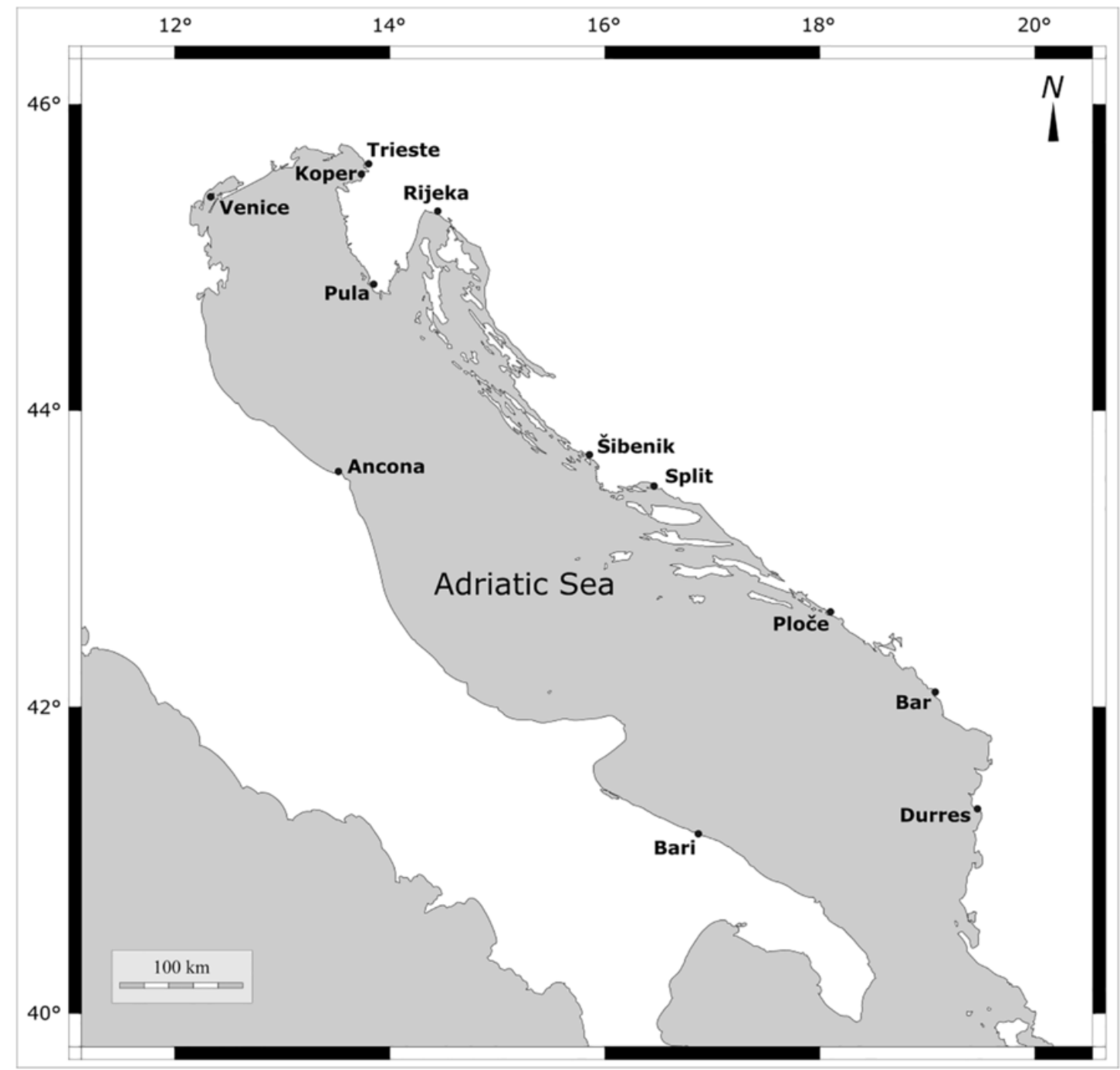

Fig. 1. Map showing the location of the Adriatic ports where samples were collected (Mediterranean Sea)

Table 1

List of the 12 ports investigated in the study and BW discharge data. The total number of vessels is reported as average number per month; the estimates of BW discharged in each port are reported as average volume discharged per month. Data refer to 2012-2015.

(Source: David et al., 2016).

\begin{tabular}{llll}
\hline Port & Country & $\begin{array}{l}\text { Total no. of } \\
\text { vessels per } \\
\text { month }\end{array}$ & $\begin{array}{l}\text { Monthly BW volume } \\
\text { discharged per month } \\
\left(\mathrm{m}^{3}\right)\end{array}$ \\
\hline Bari & Italy & 16 & 1720 \\
Ancona & ", & 105 & 3451 \\
Venice & ", & 389 & 49,409 \\
Trieste & ", & 193 & 13,109 \\
Koper & Slovenia & 188 & 57,143 \\
Pula & Croatia & 13 & 8136 \\
Rijeka & ", & 80 & 50,000 \\
Šibenik & ", & 13 & 2992 \\
Split & ", & 77 & 7857 \\
Ploče & Montenegro & 55 & 4752 \\
Bar & Albania & 150 & 8659 \\
Durres & & & 13,208 \\
\hline
\end{tabular}

\subsection{Main hydrological variables and nutrient concentrations}

At all stations, the temperature, salinity, dissolved oxygen, and turbidity profiles were measured using CTD probes equipped with previously calibrated sensors. The concentration of nutrients (nitrate, nitrite, ammonium, phosphate, and silicates) in seawater was determined using an Autoanalyzer or a spectrophotometer according to standard methods. Chlorophyll-a was measured by standard fluorometric or spectrophotometric procedures or using a fluorometer sensor integrated in the CTD probe (only in the port of Venice). See Kraus et al. (b) for further details.

\subsection{Analysis of faecal bacteria}

EC and ENT were analysed in seawater and sediment samples from all ports and adjacent urbanized areas using culture-based methods. EC abundance in seawater was assessed by Membrane Filtration (MF). An appropriate volume of water ( 1 to $200 \mathrm{ml}$ ) was vacuum-filtered (pore size, $0.22 \mu \mathrm{m}$ or $0.45 \mu \mathrm{m}$ : diameter, $47 \mathrm{~mm}$; Sartorius or Millipore) in triplicate and the filters were placed on m-FC agar plates (or on CCA agar plates, only in the Port of Bar). EC abundance in sediment was estimated by the MF technique in all ports except Trieste, Šibenik, and 
Split, where the Most Probable Number (MPN) technique was used. For MF, triplicate aliquots ( 1 to $5 \mathrm{~g}$ ) of wet sediment were mixed (volume/ volume $1: 5$ or 1:10) with sterile seawater or sterile physiological solution $(0.8 \% \mathrm{NaCl})$, vigorously shaken, and sonicated to dislodge bacteria from sediment particles (Luna et al., 2010, references therein). After sonication, aliquots $(1 \mathrm{ml})$ of undiluted and 10-fold serial dilutions of the supernatant were filtered as described above and filters were placed on m-FC agar plates. Plates were incubated at $44.5^{\circ} \mathrm{C}$ for $24 \mathrm{~h}$. Blue colonies were considered as presumptive $E$. coli and randomly isolated for identity confirmation. Their abundance was reported as CFU (colony-forming units) $100 \mathrm{ml}^{-1}$ of water or CFU $100 \mathrm{~g}^{-1}$ (dry weight) of sediment. The MPN method involved the standard five-tube MPN technique (ISO 7251:1993). Briefly, $5 \mathrm{~g}$ of wet sediment was diluted in a 10 -fold series using sterile physiological solution $(0.9 \% \mathrm{NaCl})$. Aliquots $(1 \mathrm{ml})$ of undiluted sediment and at least 3 consecutive dilutions were inoculated into 5 lactose broth tubes $(9 \mathrm{ml})$ with inverted Durham tubes. After incubation at $36 \pm 0.5^{\circ} \mathrm{C}$ for $24 \mathrm{~h}$, tubes developing turbidity and gas were considered as presumptive positives. From each positive tube, $100 \mu \mathrm{l}$ aliquots were placed into $10 \mathrm{ml}$ of EC broth and incubated at $44^{\circ} \mathrm{C}$ for $24 \mathrm{~h}$; tubes developing turbidity and gas were confirmed as positives. To complete the E. coli assay, indole production was tested by placing a loopful of broth from each gassing EC tube into tubes containing Tryptone Water. After $24 \mathrm{~h}$ incubation at $44^{\circ} \mathrm{C}, 5$ drops of Kovac's reagent were added to the culture broth. The presence of indole was demonstrated by formation of a red-violet complex on the surface, due to reaction with the aldehyde group of p-dimethyleminobenzaldehyde. In the case of MPN, EC abundance was reported as MPN $100 \mathrm{~g}^{-1}$ (dry weight) of sediment. Throughout the procedure, the equipment was flame-sterilized between samples. Method blanks containing only sterile seawater or sterile physiological solution were used to ensure aseptic technique and sterilization between samples.

ENT abundance in seawater and sediment samples was assessed by MF with the same sterilization and control procedures described above. For seawater analysis, appropriate volumes (from 1 to $200 \mathrm{ml}$ ) were filtered in triplicate as described above and filters were placed on Slanetz Bartley agar plates. For sediment analysis the MF technique and sample preparation were as described above. Again, the samples collected in the ports of Trieste, Sibenik, and Split were assessed by the MPN method. Plates were incubated at $37^{\circ} \mathrm{C}$ for $24-48 \mathrm{~h}$. Red or reddish-brown colonies were considered as presumptive ENT and randomly isolated for identity confirmation. Their abundance was reported as CFU $100 \mathrm{ml}^{-1}$ of water or CFU $100 \mathrm{~g}^{-1}$ (dry weight) of sediment. For the analysis of sediment according to the MPN technique, samples were diluted as described above for EC, and inocula were cultured in azide dextrose broth at $36 \pm 1{ }^{\circ} \mathrm{C}$ for $24+24 \mathrm{~h}$. After incubation, tubes developing turbidity and gas were considered as presumptive positives. From each positive tube, $1 \mathrm{ml}$ of cultured broth was placed into $9 \mathrm{ml}$ of ethyl violet azide broth and incubated at $36 \pm 1{ }^{\circ} \mathrm{C}$ for $24 \mathrm{~h}$. Tubes developing turbidity and a violet deposit were confirmed as positives. In this case, ENT abundance was reported as MPN $100 \mathrm{~g}^{-1}$ (dry weight) of sediment.

\section{4. $q P C R$ analysis}

FIB abundance was determined by qPCR only in seawater and sediments from the port of Venice, one of the largest and most contaminated of those assayed, which was selected as a model site. Seawater samples (11) were filtered through $0.22 \mu \mathrm{m}$ cellulose nitrate membrane filters (Sartorius) and stored at $-20^{\circ} \mathrm{C}$ until processing. Microbial DNA was extracted from each filter using the PowerWater ${ }^{\circledR}$ DNA Isolation Kit (MoBio Laboratories). For sediment analysis, DNA was extracted from $1 \mathrm{~g}$ of each sediment sample (which had been stored at $-20^{\circ} \mathrm{C}$ ) using the PowerSoil ${ }^{\circledR}$ DNA Isolation Kit (MoBio Laboratories). DNA extraction from water and sediment was performed according to the manufacturer's instructions, with slight modifications made to increase DNA yield and quality. In particular, two vortexing steps (2min at maximum speed, each preceded by incubation at $70^{\circ} \mathrm{C}$ for $5 \mathrm{~min}$ ) were added to the single vortexing step recommended by the manufacturer, and a further washing step with Solution C5 was added to remove contaminants. To check for the potential contamination of the reagents used, for each sampling event a water sample filtration blank (consisting of a known volume of sterile milliQ water) was filtered and processed along with the samples. The blank samples were processed for DNA extraction and for the subsequent qPCR quantification assay for EC and ENT (indicated below). The absence of fluorescence growth curve during qPCR analysis of the blank samples consistently indicated the absence of contamination, or of false positive signals. DNA concentrations were determined by spectrophotometry and DNA was stored at $-80^{\circ} \mathrm{C}$ until use. The primer sets F395 and R490, targeting the 16S rDNA of E. coli (Penders et al., 2005), and ECST748F and ENC854R, targeting the 23S rDNA of Enterococcus spp. (Haugland et al., 2005), were used for qPCR. Reactions were run using a Rotor-Gene $Q$ machine (Qiagen) in a $15 \mu l$ volume containing $7.5 \mu$ l of SYBRgreen qPCR Mastermix (Qiagen), $0.15 \mu \mathrm{l}$ of each primer $(100 \mathrm{nM}), 1 \mu \mathrm{l}$ of DNA template, and ultrapure MilliQ water in the following thermal conditions: $95^{\circ} \mathrm{C}$ for $10 \mathrm{~min}$, followed by $40 \mathrm{cy}$ cles at $95^{\circ} \mathrm{C}$ for $10 \mathrm{~s}$ and $60^{\circ} \mathrm{C}$ for $45 \mathrm{~s}$, and a final melting curve analysis (from $59^{\circ} \mathrm{C}$ to $99^{\circ} \mathrm{C}$ for EC, and from $54^{\circ} \mathrm{C}$ to $99^{\circ} \mathrm{C}$ for ENT, with $0.5^{\circ} \mathrm{C} / 10 \mathrm{~s}$ increments per step). All reactions were run in triplicate, using undiluted aliquots of either seawater or sediment DNA together with 10-fold and 100-fold dilutions to test for possible PCR inhibition. These analyses showed that undiluted DNA extracts in several instances (especially in the case of sediment samples) were inhibited, as demonstrated by a threshold cycle $(\mathrm{Ct})$ delay between $\mathrm{QPCR}$ results of these DNA extracts and their serial 10 -fold dilutions $(1: 10$ and $1: 100)$. While the expected $\mathrm{Ct}$ difference between 10-fold dilutions in the absence of inhibition is 3.32, this difference was, in our inhibited samples, between 1 and 2 cycles less than expected without inhibition (data not reported). Consequently, the calculations were performed, in these cases, on those dilutions (1:10 or 1:100) which didn't show the expected Ct difference. The standard calibration curve was generated using purified 16S rDNA and $23 \mathrm{~S}$ rDNA amplicons obtained by PCR reactions performed using DNA from E. coli and Enterococcus faecalis strains from our culture collection and the primers used for qPCR. The amplicons were purified using a Gene Elute PCR Clean-up system (Sigma-Aldrich) and quantified using ND-1000 Nanodrop (Thermo Scientific). The standard calibration curves were always performed in triplicate with regression coefficients close to 1 , and showed a linear increase in the range of DNA concentrations used. Detailed descriptions of the qPCR assays and data processing are reported in previous publications (Luna et al., 2012; Di Cesare et al., 2013). The melting curve analyses always highlighted that the qPCR assays were highly specific for the two target FIB, pointing out the presence of a clear melting peak in the range of the melting temperatures 80.5-81.5 ${ }^{\circ} \mathrm{C}$ for EC and for ENT, as well as the lack of nonspecific products. FIB abundance was expressed as cell equivalents (CE) $100 \mathrm{ml}^{-1}$ of seawater or $\mathrm{CE}^{-1}$ of sediment. For calculation of cell equivalents from gene copies, we considered 7 copies of 16S rDNA per genome for EC, and 4 copies of 23S rDNA per genome for ENT (as used previously in Di Cesare et al., 2013 and references therein). Although it is known that multiple copies of enterococcal 23S rDNA are found in the Enterococcus genome (ranging from 4 to 6 , as reported in the rRNA operon database: https://rrndb.umms.med.umich.edu/), and that the number of 23S rRNA gene copies per genome has not been determined for all ENT species, the use of 4 as conversion factor in qPCR analyses poten- 
tially introduces a bias but, at the same time, allows the comparison with most of the available studies, as this factor is the one used worldwide for qPCR determinations of ENT.

\subsection{Statistical analysis}

Spearman rank correlation analysis was performed to test relationships between the abundance of culturable EC and ENT, between their abundance in water and sediments, and between abundance assessed by culture and by qPCR. Correlation coefficients ( $r$ ) were considered significant at $\mathrm{p}$ values $<0.05$. Differences in the abundance of culturable FIB between ports and adjacent areas and between culture and qPCR results were tested using one-way analysis of variance (ANOVA). Differences in the abundance of culturable FIB between sampling sites and seasons were assessed using two-way ANOVA. Multivariate multiple regression analysis was performed to explore the relationships between environmental and microbial data using the Distance-based Linear Modelling (DistLM) procedure applied on the whole FIB dataset and including the main environmental variables (temperature, salinity, dissolved oxygen, total nitrogen, phosphate, silicates and chlorophyll-a concentrations) as predictor variables. One-way ANOVA, two-way ANOVA, and DistLM were performed using the statistical R-Software (R-Cran project, http://cran.r-project.org/).

\section{Results}

\subsection{Environmental variables in the Adriatic ports and adjacent areas}

The results of the analyses of the main environmental variables in the 12 ports are summarized in Table S1. Salinity ranged from 4.42 to 38.31 PSU. It was very similar in all ports except for Šibenik and Ploče, which were characterized by strong freshwater inputs, whereas the freshwater inputs affecting the other ports exerted a more limited influence. The temperature ranged from 6.08 to $29.1^{\circ} \mathrm{C}$. The lowest temperatures were recorded in the ports of Šibenik $\left(6.08^{\circ} \mathrm{C}\right)$ and Venice $\left(6.14^{\circ} \mathrm{C}\right)$, whereas the highest temperature $\left(29.1^{\circ} \mathrm{C}\right)$ was measured in
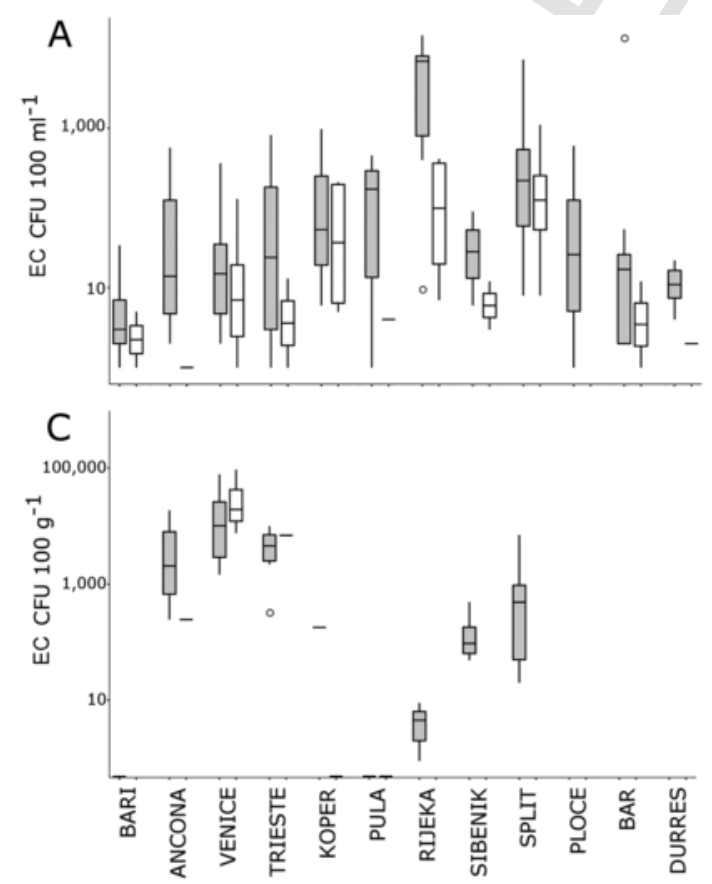

the port of Venice, at a station that is affected by water discharges from the cooling water system of a nearby thermoelectric plant. Analysis of nutrient content showed that total nitrogen was highest in the port of Durres (average, $27.8 \mu \mathrm{moll}^{-1}$ ) and lowest in the port of Rijeka (average, $2.65 \mu \mathrm{moll}^{-1}$ ), whereas silicates were highest in the ports of Šibenik and Venice (Table S1). The concentration of chlorophyll-a was highest in the ports of Šibenik (up to $17.6 \mathrm{mgm}^{-3}$ ) and Venice (up to $32.72 \mathrm{mg} \mathrm{m}^{-3}$ ) and lowest in the ports of Bar and Rijeka (average, 0.14 and $0.31 \mathrm{mgm}^{-3}$, respectively). More detailed information about the spatio-temporal dynamics of the environmental variables in the 12 ports is found in Kraus et al. (b).

\subsection{Patterns of FIB abundance in the Adriatic ports and adjacent areas}

The FIB abundance data are summarized in Fig. 2A-D. As regards seawater, EC abundance (Fig. 2A) ranged from undetectable to 14,500 CFU $100 \mathrm{ml}^{-1}$ (port of Rijeka), whereas ENT abundance (Fig. 2B) ranged from undetectable to $24,000 \mathrm{CFU} 100 \mathrm{ml}^{-1}$ (port of Split). As regards the smaller sediment dataset, EC abundance ranged from undetectable to $93,750 \mathrm{CFU} 100 \mathrm{~g}^{-1}$ (Fig. 2C) and ENT from undetectable to $880,342 \mathrm{CFU} 100 \mathrm{~g}^{-1}$ (both in port of Venice) (Fig. 2D). Positive correlations were found between the abundance of EC and ENT in seawater $(\mathrm{n}=173, \mathrm{r}=0.759, \mathrm{p}<0.001)$ and sediments $(\mathrm{n}=85, \mathrm{r}=0.761$, $\mathrm{p}<0.001$ ), whereas there was no significant correlation between the abundance of EC in seawater and sediments nor between ENT abundance in seawater and sediments. Assuming that the specific density of water was $1 \mathrm{~g} \mathrm{ml}^{-1}$, the average abundance of EC across the whole dataset on a unit weight basis (CFU $100 \mathrm{~g}^{-1}$ ) was 11.3 times higher in sediments than in the overlying water (average, 4497 vs. $444 \mathrm{CFU}$ $100 \mathrm{~g}^{-1}$, respectively), whereas ENT abundance was 95.6 times higher in sediment than in the overlying water (average, 27,109 vs. $284 \mathrm{CFU}$ $\left.100 \mathrm{~g}^{-1}\right)$.

As reported in Table S2, the abundance of EC in seawater was significantly higher (on average 19.7 times; ANOVA) in ports than in the areas outside the ports (average, 667 vs. $34 \mathrm{CFU} 100 \mathrm{ml}^{-1}$ respec-
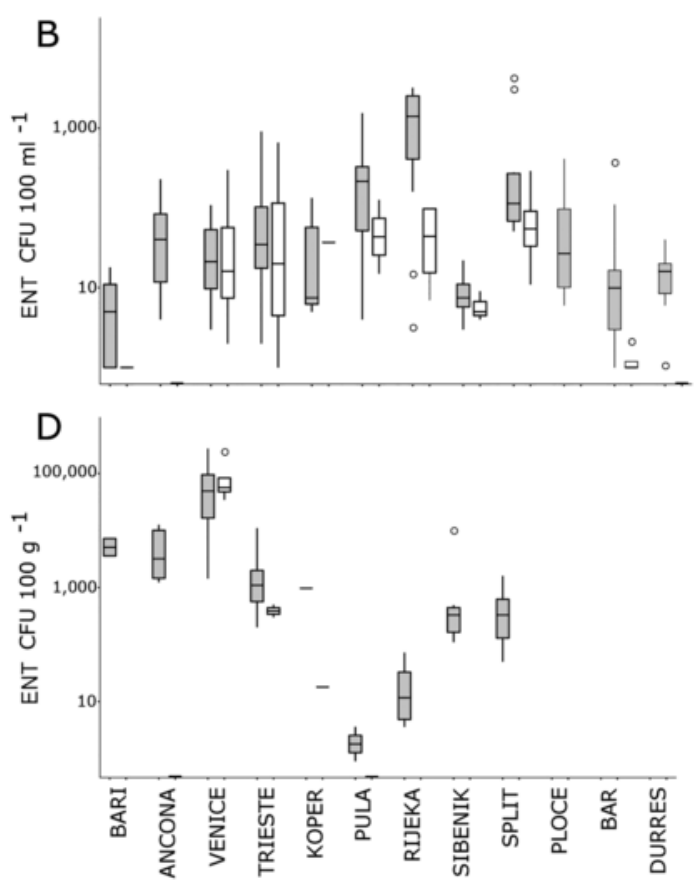

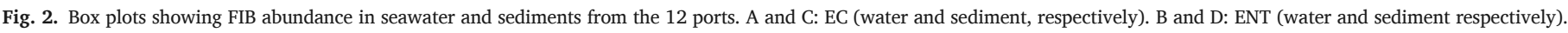

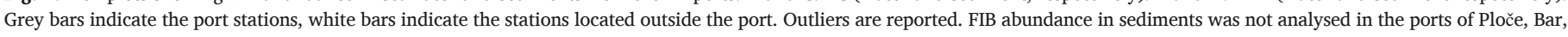
and Durres. 
tively); similarly, ENT abundance was significantly higher (on average 16.3 times) in ports than outside them (average, 436 vs, $27 \mathrm{CFU}$ $100 \mathrm{ml}^{-1}$, respectively), although in this case the level of significance was lower (ANOVA, Table S2). In sediments, the abundance of EC and ENT did not display significant differences between the port and adjacent areas (Table S2). On average, EC abundance in sediment was lower in ports (4315 CFU $100 \mathrm{~g}^{-1}$ ) than in adjacent areas (7137 CFU $100 \mathrm{~g}^{-1}$ ), whereas ENT abundance was on average 1.5 times higher in ports $\left(31,015 \mathrm{CFU} 100 \mathrm{~g}^{-1}\right)$ than in adjacent areas $\left(20,631 \mathrm{CFU} 100 \mathrm{~g}^{-1}\right)$.

\subsection{Spatial and seasonal variability of FIB abundance}

The spatial and seasonal variability of FIB in the 12 ports and four seasons was explored only in the port stations. The results of two-way ANOVA are summarized in Table 2 . In seawater, their abundance varied significantly across the 12 ports $(\mathrm{p}<0.001$ for EC and $\mathrm{p}<0.05$ for ENT), but their seasonal variability was not significant. The interaction between Site and Season was significant only for ENT in seawater, whereas in sediments there were significant spatial and seasonal differences and a significant interaction of Site and Season for both FIB (Table 2 ). The abundance data, subdivided by season and averaged on all ports, are reported in Fig. 3A (seawater) and Fig. 3B (sediment).

\subsection{Relationship between FIB abundance and environmental variables}

The relationships between the spatial-temporal abundance of the two FIB and the main environmental variables were analysed to establish whether the abundance patterns were related to the fluctuations of these variables over time. The study first tested the presence of linear relationships between FIB abundance and temperature, which is considered as the main factor influencing FIB decay in aquatic environments (Noble et al., 2004; Blaustein et al., 2013). There was a negative but weak correlation with temperature both in seawater (EC, $\mathrm{r}=-0.1268, \mathrm{p}<0.05$; ENT, $\mathrm{r}=0.144, \mathrm{p}<0.01$ ) and in sediments (EC, $r=-0.4228$; ENT, $r=-0.3019$, for both $\mathrm{p}<0.01$ ). Multivariate analysis (DistLM) involving all the environmental variables was then performed to identify which measures influenced FIB patterns. In sea- water, EC abundance was significantly related to salinity, dissolved oxygen, phosphate and chlorophyll-a, whereas ENT abundance was not significantly related to any of the variables assessed (Table 3 ). In sediments, the abundance of both FIB was significantly related only to salinity and dissolved oxygen (Table 4).

\subsection{FIB quantification by $q P C R$}

The results of qPCR are summarized in Fig. 4A-D. Compared with the culture-based method, the molecular approach provided consistently higher estimates of FB abundance in both seawater and sediments (both $\mathrm{p}<0.01$, ANOVA). In seawater, EC abundance was 21- to 112-fold higher (Fig. 4A) and ENT abundance was from 6- to 49-fold higher (Fig. 4B). In one instance (a station out of the port), a sample yielded no culturable $E$. coli whereas it yielded a measurable qPCR signal. The comparison of qPCR and culture-based data yielded significant positive correlations, although the correlation for EC was weaker $(\mathrm{r}=0.528, \mathrm{p}<0.05, \mathrm{n}=18)$ than the one found for ENT $(\mathrm{r}=0.915$, $\mathrm{p}<0.001, \mathrm{n}=18$ ). In sediments, EC abundance was 5.6- to 95.3-fold higher (Fig. 4C) and ENT abundance was from 10.6- to 174.9-fold higher (Fig. 4D). In one case (the same station mentioned above), the sample yielded no culturable EC or ENT, but it did yield a measurable qPCR signal for both. Also in sediments, FIB abundance was significantly higher as determined by qPCR than by culture (both $\mathrm{p}<0.01$, ANOVA). However, no correlations were found when the results of the two methods were compared.

\section{Discussion}

This is the first study investigating the patterns and spatial-temporal dynamics of seawater and sediment faecal contamination in a large number of commercial ports and adjacent urbanized areas situated in the same basin. Despite increasing awareness of faecal pollution in ports (Chiaretti et al., 2014), investigations of FIB levels in seawater or sediments are few and sparse (Jeng and Han, 1994; Wong et al., 1995; Luna et al., 2012; Ng et al., 2015; Dheenan et al., 2016), and no systematic studies have investigated the spatial-temporal dynamics of FIB contamination in ports. According to the present findings, FIB pollution was high in all ports, often much higher than in the adjacent coastal

Table 2

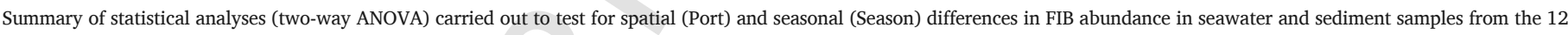

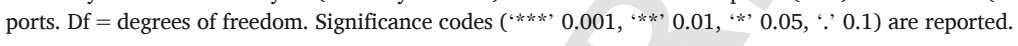

\begin{tabular}{|c|c|c|c|c|c|}
\hline & $\mathrm{Df}$ & Sum square & Mean square & F value & $\mathrm{p}$ \\
\hline \multicolumn{6}{|l|}{ Seawater } \\
\hline \multicolumn{6}{|l|}{ EC } \\
\hline Port & 11 & $275,517,104$ & $25,047,009$ & 6.130 & $1.27 \mathrm{e}-07 * * *$ \\
\hline Season & 3 & $13,940,065$ & $4,646,688$ & 1.137 & 0.338 \\
\hline Port:Season & 27 & $64,661,569$ & $2,394,873$ & 0.586 & 0.944 \\
\hline Residuals & 101 & $412,657,651$ & $4,085,719$ & & \\
\hline \multicolumn{6}{|l|}{ ENT } \\
\hline Port & 11 & $87,253,104$ & $7,932,100$ & 2.100 & 0.0272 * \\
\hline Season & 3 & $15,112,305$ & $5,037,435$ & 1.334 & 0.2679 \\
\hline Port:Season & 25 & $154,293,841$ & $6,171,754$ & 1.634 & 0.0470 * \\
\hline Residuals & 97 & $366,352,780$ & $3,776,833$ & & \\
\hline \multicolumn{6}{|l|}{ Sediment } \\
\hline \multicolumn{6}{|l|}{ EC } \\
\hline Port & 8 & $2.584 \mathrm{e}+09$ & $323,057,036$ & 4.324 & $0.0005 * * *$ \\
\hline Season & 3 & $2.133 e+09$ & $710,939,932$ & 9.515 & $4.28 \mathrm{e}-05 * * *$ \\
\hline Port:Season & 10 & $3.454 \mathrm{e}+09$ & $345,351,344$ & 4.622 & $0.00011 * * *$ \\
\hline Residuals & 51 & $3.811 \mathrm{e}+09$ & $74,718,988$ & & \\
\hline \multicolumn{6}{|l|}{ ENT } \\
\hline Port & 8 & $2.040 \mathrm{e}+11$ & $2.551 e+10$ & 3.127 & $0.0063 * *$ \\
\hline Season & 3 & $1.076 \mathrm{e}+11$ & $3.586 e+10$ & 4.397 & $0.0082 * *$ \\
\hline Port:Season & 8 & $1.797 e+11$ & $2.246 \mathrm{e}+10$ & 2.754 & 0.0138 * \\
\hline Residuals & 48 & $3.916 \mathrm{e}+11$ & $8.157 e+09$ & & \\
\hline
\end{tabular}



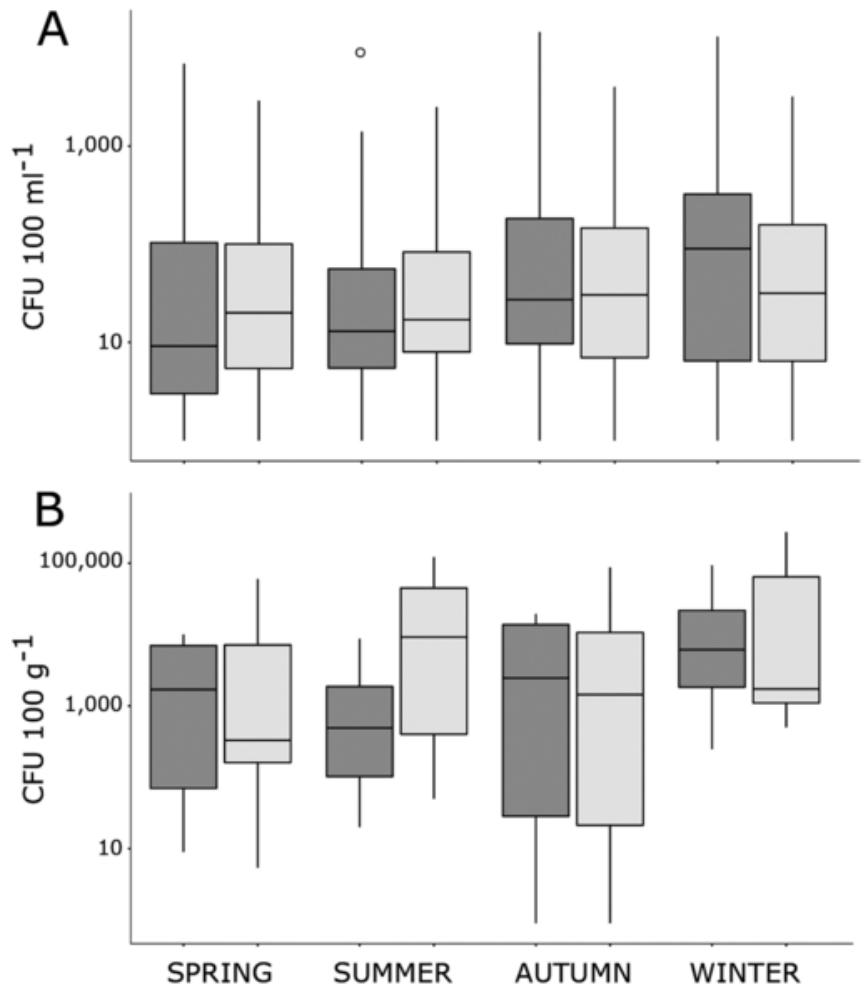

Fig. 3. Box plots showing the abundance of EC (dark grey) and ENT (light grey) in seawater (A) and sediment (B) averaged per season. Data from the stations located outside the ports are not included.

Table 3

Summary of DistLM statistical analyses carried out to test for relationships between FIB abundance in seawater and selected environmental variables in the 12 ports. Df $=$ degrees

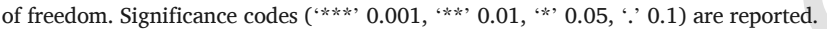

\begin{tabular}{|c|c|c|c|c|}
\hline \multicolumn{5}{|l|}{ Seawater } \\
\hline & Estimate & Std. error & $\mathrm{t}$ & $\mathrm{p}$ \\
\hline \multicolumn{5}{|l|}{ EC } \\
\hline Temperature & 32.7 & 51.99 & -0.629 & 0.531 \\
\hline Salinity & -197.48 & 80.13 & -2.464 & $0.0157 *$ \\
\hline Oxygen & -32.29 & 13.35 & -2.419 & $0.0177 *$ \\
\hline $\begin{array}{l}\text { Total } \\
\text { nitrogen }\end{array}$ & -10.6 & 18.55 & -0.572 & 0.569 \\
\hline Phosphate & 9235.06 & 1263.73 & 7.308 & $\underset{* * *}{1.37 \mathrm{e}-10}$ \\
\hline Silicates & 15.86 & 59.64 & 0.266 & 0.791 \\
\hline Chl-a & -406.38 & 126.81 & -3.205 & $0.0019 * *$ \\
\hline \multicolumn{5}{|c|}{ Multiple $\mathrm{R}^{2}: 0.4688$} \\
\hline \multicolumn{5}{|c|}{ F-Statistic: 10.72 on 7 and 85 Df } \\
\hline \multicolumn{5}{|l|}{ ENT } \\
\hline Temperature & -62.896 & 64.528 & -0.975 & 0.332 \\
\hline Salinity & -93.639 & 99.456 & -0.942 & 0.349 \\
\hline Oxygen & -17.13 & 16.568 & -1.034 & 0.304 \\
\hline \multicolumn{4}{|l|}{ nitrogen } & 0.801 \\
\hline Phosphate & 1188.651 & 1568.509 & 0.758 & 0.451 \\
\hline Silicates & -82.906 & 74.018 & -1.12 & 0.266 \\
\hline Chl-a & 90.034 & 157.392 & 0.572 & 0.569 \\
\hline \multicolumn{5}{|c|}{ Multiple $\mathrm{R}^{2}: 0.04553$} \\
\hline \multicolumn{5}{|c|}{ F-Statistic: 0.5792 on 7 and 85 Df } \\
\hline \multicolumn{5}{|c|}{ p-Value: 0.771} \\
\hline
\end{tabular}

sea. This trend was especially apparent in seawater, where the abundance of EC and ENT (which reached concentrations up to 14,500 and $24,000 \mathrm{CFU} 100 \mathrm{ml}^{-1}$, respectively) was on average, across our entire dataset, 19.7 and 16.3 times higher than at the out of port stations. However, differences between in port and out of port samples varied,
Table 4

Summary of DistLM statistical analyses carried out to test for relationships between FIB abundance in sediment and selected environmental variables in the 12 ports. Df $=$ degrees

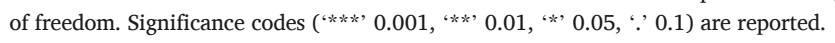

\begin{tabular}{|c|c|c|c|c|}
\hline \multicolumn{5}{|l|}{ Sediment } \\
\hline & Estimate & $\begin{array}{l}\text { Std. } \\
\text { error }\end{array}$ & $\mathrm{t}$ & $\mathrm{p}$ \\
\hline \multicolumn{5}{|l|}{ EC } \\
\hline Temperature & 230.22 & 155.85 & -1.477 & 0.150 \\
\hline Salinity & -4367.74 & 1116.12 & -3.913 & $\underset{* * *}{0.00051}$ \\
\hline Oxygen & 46.11 & 18.35 & 2.512 & $0.01781 *$ \\
\hline $\begin{array}{l}\text { Total } \\
\text { nitrogen }\end{array}$ & -62.81 & 111 & -0.566 & 0.576 \\
\hline Phosphate & -729.8 & 8319.35 & -0.088 & 0.931 \\
\hline Silicates & 326.62 & 249.42 & 1.309 & 0.201 \\
\hline Chl-a & 746.58 & 840.37 & 0.888 & 0.382 \\
\hline \multicolumn{5}{|c|}{ Multiple $\mathrm{R}^{2}: 0.4959$} \\
\hline $\begin{array}{l}\text { F-Statistic: } 4.0 \\
\text { p-Value: } 0.003 \\
\text { ENT }\end{array}$ & 7 and $29 \mathrm{Df}$ & & & \\
\hline Temperature & 145.16 & 114.7 & 1.266 & 0.216 \\
\hline Salinity & -5906.62 & 821.4 & -7.191 & $\begin{array}{l}\text { 6.46e-08 } \\
* * *\end{array}$ \\
\hline Oxygen & 78.81 & 13.51 & 5.835 & $\underset{* * *}{2.51 \mathrm{e}-06}$ \\
\hline $\begin{array}{l}\text { Total } \\
\text { nitrogen }\end{array}$ & -100.27 & 81.69 & -1.227 & 0.230 \\
\hline Phosphate & -4710.85 & 6122.6 & -0.769 & 0.448 \\
\hline Silicates & 244.09 & 183.56 & 1.33 & 0.194 \\
\hline Chl-a & -918.62 & 618.47 & -1.485 & 0.148 \\
\hline \multicolumn{5}{|c|}{ Multiple $\mathrm{R}^{2}: 0.6633$} \\
\hline \multicolumn{5}{|c|}{ F-Statistic: 8.16 on 7 and 29 Df } \\
\hline
\end{tabular}

and were greater in some ports (e.g. Ancona, Šibenik, and Rijeka) and smaller in others (e.g. Venice), where they were similar. One reason for the differences found between these values may be explained by the fact that, in some cases, the stations outside the port were quite far from potential faecal sources, whereas in others (e.g. Venice), they were close to the city centre, which is a source of significant FIB inputs (Quero et al., 2015; Perini et al., 2015).

As regards sediments, the samples collected in ports typically showed marked faecal pollution - with abundances of culturable FIB reaching 93,750 and $880,342 \mathrm{CFU} 100 \mathrm{~g}^{-1}$ for EC and ENT, respectively - whereas the values measured in out of port samples were sometimes similar or lower than those found in ports. The different pattern observed in sediments and seawater may be ascribed to the different FIB survival behaviours in water and sediment (Luna et al., 2010), or by a different ability of the cultivation-based methods here used to detect false positive rates in sediments and water samples. In fact, although the factors underpinning FIB persistence in sediments are still poorly understood (Pachepsky and Shelton, 2011), sediments promote FIB survival (Anderson et al., 2005) in the extra-enteric environment, since binding to the sediment surface affords physical and chemical protection against biotic and abiotic stress (Hassard et al., 2016). The marked faecal contamination measured in sediments in the vicinity of port areas may depend both on other point and non-point sources outside the port and on mechanisms involving FIB transport from the port and subsequent settlement in adjacent areas. Indeed the action of waves, the transit of ships, and other factors (such as periodic bottom dredging) may induce the resuspension of pollutants found in sediments and their transport to adjacent areas (Zhang et al., 2007; Laitano et al., 2015), making the ports themselves significant sources of contamination of the surrounding coastal environment. The present findings indicate that port sediments are important FIB hotspots, as previously reported for some lake marinas in the US, where E. coli abundance reached $5.00 \times 10^{5} \mathrm{CFUg}^{-1}$ (An et al., 2002), and suggest 

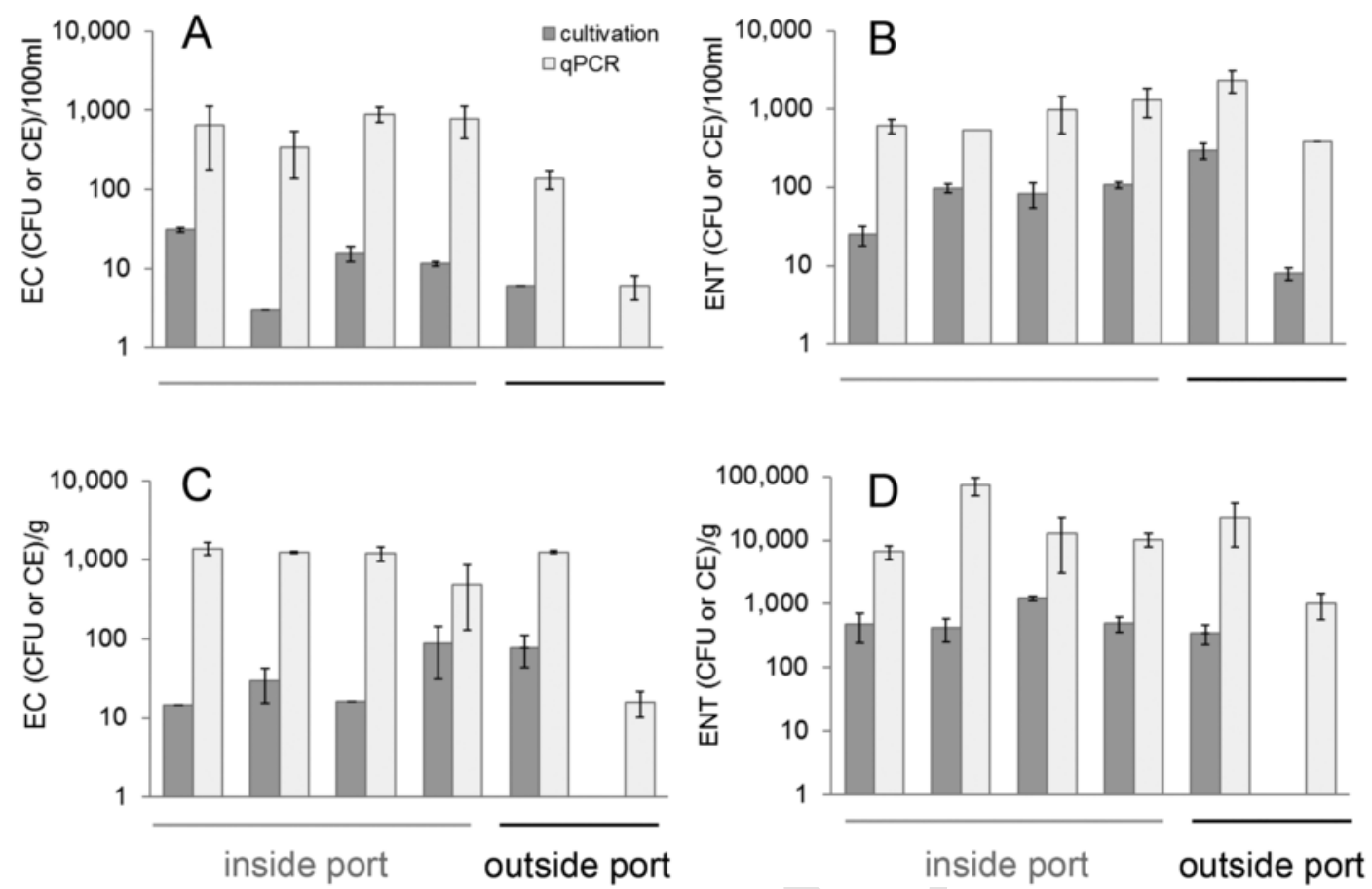

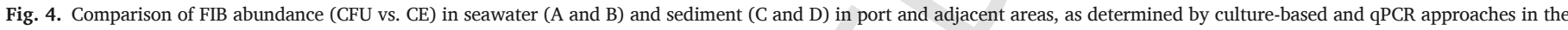

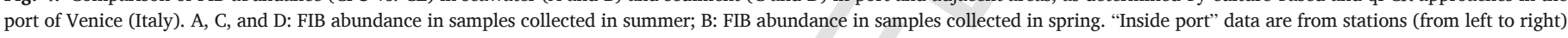
VEbwIN, VEbwW2, VEbwW3 and VEbwP1. "Outside port" data are from stations (from left to right) VEbw7M and VErefW4 (A and B) and VEbw7M and VEancPTF (C and D).

that they may serve as vehicles for pathogen exposure, thus posing potential threats to human and ecosystem health. Since public health regulations do not envisage sampling of sediments or beach sand (Vogel et al., 2017), and since analysis of recreational waters is mostly confined to seawater (Zhang et al., 2015), our data highlight the need for sediment monitoring (Lee et al., 2006; Luna et al., 2010), to improve water quality management practices and achieve a more thorough understanding of the risk they pose to human health. We suggest that the sediment monitoring should be performed also during activities such as the Port Baseline Surveys that are performed in the framework of BW management actions.

Although FIB abundance in port areas showed wide spatio-temporal fluctuations, statistical analysis did not document a significant seasonal variability in seawater, suggesting that the abundance variations in port seawater do not depend on season, unlike the case of pathogens that are autochthonous to the aquatic environment (e.g., Vibrio species; Oberbeckmann et al., 2012). Previous studies of the seasonal variability of FIB in water have described contrasting results. Season has been reported to regulate FIB abundance in surface freshwater in a hydro-climatologically complex region in British Columbia (Laurent and Mazumder, 2014), where the variability was mostly driven by snow-melt and rainfall-induced runoff. According to a study of five lake marinas in the US (An et al., 2002), E. coli varied on a seasonal basis and showed a lower abundance in summer, whereas at two freshwater bathing sites in the UK, FIB values showed no seasonal variability (Obiri-Danso and Jones, 1999). Most studies describing FIB seasonal variations in water have related them to rainfall and to seasonal temperature changes (Hong et al., 2010; Pan and Jones, 2012). Physicochemical variables, including temperature, ultraviolet radiation, $\mathrm{pH}$, salinity, and oxygen and nutrient concentrations, are known to affect FIB survival in aquatic systems; for instance, higher temperatures may exert adverse effects (Ishii et al., 2006; An et al., 2002). However, the dependence of $E$. coli inactivation rates on temperature has been reported to vary across water sources (e.g. agricultural runoff, pristine water, groundwater, lakes, rivers, seawater and wastewater; Blaustein et al., 2013). The present study found negative, although weak, linear relationships between FIB abundance and temperature, suggesting that temperature is not the main factor influencing their survival in the 12 ports sampled. Conversely, although multivariate analysis failed to highlight any significant relationship between FIB abundance and temperature, it found significant correlations with salinity, FIB abundance being higher in less saline port water. An experimental study has demonstrated higher FIB survival rates at low salinity values and a greater resistance to salinity variations of ENT compared with faecal coliforms (Bordalo et al., 2002). Our data are in line with studies reporting higher FIB levels at sites affected by freshwater inputs (Lipp et al., 2001), and suggest that such inputs are likely to be important point-sources of faecal pollution in ports, as in the case of the port of Koper, which receives freshwater from the estuary of the river Rižana (Faganeli and Turk, 1989) as well as faecally-polluted waters from the near wastewater treatment plant of Koper. Notably, multivariate analysis highlighted significant correlations between FIB abundance and phosphate concentrations, suggesting a role for nutrients in the growth of faecal microbes after their release into the port environment.

Unlike seawater, port sediments exhibited a significant seasonal variability of FIB abundance. Data on the dynamics of faecal pollutants in coastal sediments are limited. A pioneering study found no evidence of seasonal variability of faecal coliforms in estuarine sediments (Carney et al., 1975). However, a later investigation reporting no seasonal FIB variation in sediments found that, as in our study, FIB abundance was always higher in sediments than in the overlying water (Obiri-Danso and Jones, 1999). According to Ishii et al. (2007), E. coli counts in lake sediments increased in summer and early autumn (July-September). The significant albeit weak negative relationships, found between FIB and temperature in our study, are in line with previous works which identified temperature as an important factor in FB survival in sediments (Garzio-Hadzick et al., 2010). At the same time, multivariate analysis demonstrated that EC and ENT abundance in our sediment samples were significantly related to salinity and dissolved oxygen. Although other sediment variables, such as particle size distri- 
bution and organic matter content, may also affect FIB survival (Pachepsky and Shelton, 2011), our data suggest that port sediments collected close to freshwater inputs are more affected by faecal pollution.

It is well established that chemical pollution, which is common in ports, is the consequence of the several human activities taking place in these areas. Industrial production, trade, tourism, and urbanization are direct and indirect sources of macronutrients, trace elements, aliphatic compounds, aromatic hydrocarbons, and xenobiotics (Renzi et al., 2009), which are directly discharged into the water or are transported by water runoff and leaching. Thus, ports are sinks for a wide range of pollutants produced by port activities and nearby urbanized areas. As far as the faecal pollution is concerned, potential contamination routes in ports include dumping of sewage, surface water runoff, discharges from ships, and riverine inputs. A large number of ports receive, or have long received, untreated or partially treated sewage from neighbouring cities (Xu et al., 2014); moreover, some ports are situated in estuaries, bays, or artificial enclosed systems, where water circulation is limited. In a study combining geographical mapping systems and multivariate analysis, Dheenan et al. (2016) have demonstrated that Rangat Bay (Middle Andaman, India) is an FIB hotspot, and hypothesized that FIB accumulation is the result of continuous discharges from the harbour and neighbouring settlements. Our data, by demonstrating variable but marked faecal contamination of water and sediment in 12 Adriatic ports, suggest that a variety of point and non-point sources may be responsible. To identify these sources in each port is essential; complementary approaches, such as microbial source tracking (Harwood et al., 2014), may be employed to find and quantify them. Since numerous water-borne diseases can be acquired through exposure to pathogen-polluted waters, the present findings stress that port areas, and especially routine activities such as bottom dredging (that mobilizes sediments) and BW exchange, pose a significant public health risk.

Finally, the study assessed the value of qPCR as a fast alternative to culture-based methods to measure FIB abundance. Since FIB monitoring is performed to ensure port water quality and protect human health, rapid and robust monitoring tools capable of quantifying FIB and bacterial pathogens are essential. The superiority of qPCR in EC and ENT quantification has been documented in recreational waters (Noble et al., 2010; Haugland et al., 2005), sediments (Luna et al., 2010; Di Cesare et al., 2013), and rainwater tanks (Ahmed et al., 2012). However, its value in heavily contaminated port areas was first tested in the present study. qPCR yielded significantly higher estimates of FIB abundance compared with culture-based methods both in seawater and sediment samples, in line with earlier method comparisons studies (Ahmed et al., 2012; Oliver et al., 2016b). Notably, the qPCR approach used here is more labour-intensive than MF and requires greater training, but it provided faster water quality assessments than culture-based methods (Ferretti et al., 2013). It should also be stressed that the higher abundance estimates obtained by qPCR may be biased by overestimation, due to the amplification of recently dead cells and of detrital DNA, which is known to persist in the environment. The problem can be overcome by using propidium monoazide (PMA) to differentiate live from dead cells (Bae and Wuertz, 2009; Eichmiller et al., 2014). Overall, our findings indicate that $\mathrm{qPCR}$ is a useful tool that can provide a greater understanding of FIB survival and variability in ports, with clear benefits for port management. Notably, port management activities also include the monitoring of BW microbial compliance, and emerging studies are suggesting the adoption of modern, molecular techniques to detect and quantify microbes in BW and ports (Lymperopoulou and Dobbs, 2017, and references therein), thus overcoming the lengthy procedures associated with current culture-based methods.

\section{Conclusions}

This study provides the largest dataset produced for port areas to date. It demonstrates that large numbers of bacteria of faecal origin are found in ports and that their abundance is characterized by a marked spatio-temporal variability. The study supplies needed data regarding the range, abundance, and variability of faecal indicators in port water and sediments, thus providing robust baseline knowledge of faecal contamination in large commercial ports. It also provides support to the use of multivariate statistical tools, such as the multivariate multiple regression analysis here used, to develop or improve management strategies. Moreover, since port activities are expected to increase in the near future, as a consequence of growing maritime traffic and of trade globalization, this body of information can prove useful for public health purposes and to support decision-makers in performing environmental quality assessments. It can help plan and manage port activities such as sediment dredging and BW exchange, which have the potential to spread microbial pathogens from the port to the nearby coastal sea and to transmit water-borne diseases to humans through exposure to pathogen-polluted port seawater or sediment.

\section{Uncited reference \\ Alm et al., 2003}

\section{Acknowledgments}

This publication has been produced with the financial assistance of the IPA Adriatic Cross-Border Cooperation Programme - strategic project Ballast Water Management System for Adriatic Sea Protection (BALMAS) (PROJECT CODE $1^{\circ}$ STR/0005). The contents of this publication are the sole responsibility of authors and can under no circumstances be regarded as reflecting the position of the IPA Adriatic Cross-Border Cooperation Programme Authorities. The authors are grateful to the crews of the several research vessels and boats that were employed in sampling operations.

\section{Appendix A. Supplementary data}

Supplementary data to this article can be found online at https:// doi.org/10.1016/j.marpolbul.2018.03.050.

\section{References}

Ahmed, W., Richardson, K., Sidhu, J.P., Toze, S., 2012. Escherichia coli and Enterococcus spp. in rainwater tank samples: comparison of culture-based methods and 23S rRNA gene quantitative PCR assays. Environ. Sci. Technol. 46, 11370-11376.

Alm, E.W., Burke, J., Spain, A., 2003. Fecal indicator bacteria are abundant in wet sand at freshwater beaches. Water Res. 37, 3978-3982.

Amalfitano, S., Coci, M., Corno, G., Luna, G.M., 2015. A microbial perspective on biological invasions in aquatic ecosystems. Hydrobiologia 746 (1), 13.

An, Y.-J., Kampbell, D.H., Breidenbach, G.P., 2002. Escherichia coli and total coliforms in water and sediments at lake marinas. Environ. Pollut. 120, 771-778.

Anderson, K.L., Whitlock, J.E., Harwood, V.J., 2005. Persistence and differential survival of fecal indicator bacteria in subtropical waters and sediments. Appl. Environ. Microbiol. 71, 3041-3048.

Bae, S., Wuertz, S., 2009. Discrimination of viable and dead fecal Bacteroidales bacteria by quantitative PCR with propidium monoazide. Appl. Environ. Microbiol. 75, 2940-2944.

Blaustein, R.A., Pachepsky, Y., Hill, R.L., Shelton, D.R., Whelan, G., 2013. Escherichia coli survival in waters: temperature dependence. Water Res. 47, 569-578.

Bordalo, A.A., Onrassami, R., Dechsakulwatana, C., 2002. Survival of faecal indicator bacteria in tropical estuarine waters (Bangpakong River, Thailand). J. Appl. Microbiol. 93, 864-871.

BWD, 2006. Directive 2006/7/EC of the European Parliament and of the Council of 15 February 2006 concerning the management of bathing water quality and repealing Directive 76/160/EEC. In: http://eur-lex.europa.eu/legal-content/EN/TXT/ ?uri = CELEX:32006L0007. 
Carney, J.F., Carty, C.E., Colwell, R.R., 1975. Seasonal occurrence and distribution of microbial indicators and pathogens in the Rhode River of Chesapeake Bay. Appl. Microbiol. 30, 771-780.

Casado-Martínez, M.C., Buceta, J.L., Belzunce, M.J., DelValls, T.A., 2006. Using sediment quality guidelines for dredged material management in commercial ports from Spain. Environ. Int. 32, 388-396.

Chiaretti, G., Onorati, F., Borrello, P., Orasi, A., Mugnai, C., 2014. Coastal microbial quality of surface sediments in different environments along the Italian coast. Environ. Sci.: Processes Impacts 16, 2165-2171.

Converse, R.R., Griffith, J.F., Noble, R.T., Haugland, R.A., Schiff, K.C., Weisberg, S.A., 2012. Correlation between quantitative PCR and culture-based methods for measuring Enterococcus spp. over various temporal scales at three California marine beaches. Appl. Environ. Microbiol. 78, 1237-1242.

David, M., Penko, L., Zupančič, G., Gosar, L., 2016. Ballast water discharge assessment methods and analysis of ballast discharge patterns in the Adriatic area. In: Final Report, BALMAS Project. p. 175 http://balmas.eu/balmas-tools/knowledge-center.

Dheenan, P.S., Jha, D.K., Das, A.K., Vinithkumar, N.V., Devi, M.P., Kirubagaran, R., 2016 Geographic information systems and multivariate analysis to evaluate fecal bacterial pollution in coastal waters of Andaman, India. Environ. Pollut. 214, 45-53.

Di Cesare, A., Luna, G.M., Vignaroli, C., Pasquaroli, S., Tota, S., Paroncini, P., Biavasco, F., 2013. Aquaculture can promote the presence and spread of antibiotic-resistant enterococci in marine sediments. PLoS One 8 (4), e62838.

Eichmiller, J.J., Borchert, A.J., Sadowsky, M.J., Hicks, R.E., 2014. Decay of genetic markers for fecal bacterial indicators and pathogens in sand from Lake Superior. Water Res. 59, 99-111.

Faganeli, J., Turk, V., 1989. Behavior of dissolved organic matter in small, polluted estuary. Sci. Mar. 53, 513-521.

Ferretti, J.A., Tran, H.V., Peterson, S.J., Loftin, V., 2013. Rapid method demonstration project at four New Jersey marine beaches using real time quantitative polymerase chain reaction (qPCR). Mar. Pollut. Bull. 71, 51-63.

Field, K.G., Samadpour, M., 2007. Fecal source tracking, the indicator paradigm, and managing water quality. Water Res. 41, 3517-3538.

Garzio-Hadzick, A., Shelton, D.R., Hill, R.L., Pachepsky, Y.A., Guber, A.K., Rowland, R., 2010. Survival of manure-borne E. coli in streambed sediment: effects of temperature and sediment properties. Water Res. 44, 2753-2762.

Ghosh, U., Zimmerman, J.R., Luthy, R.G., 2003. PCB and PAH speciation among particle types in contaminated harbor sediments and effects on PAH bioavailability. Environ. Sci. Technol. 37, 2209-2217.

Harwood, V.J., Staley, C., Badgley, B.D., Borges, K., Korajkic, A., 2014. Microbial source tracking markers for detection of fecal contamination in environmental waters: relationships between pathogens and human health outcomes. FEMS Microbiol. Rev. 38, $1-40$

Hassard, F., Gwyther, C.L., Farkas, K., Andrews, A., Jones, V., Cox, B., Brett, H., Jones, D.L., McDonald, J.E., Malham, S.K., 2016. Abundance and distribution of enteric bacteria and viruses in coastal and estuarine sediments - a review. Front. Microbiol. 7, 1692.

Haugland, R.A., Siefring, S.C., Wymer, L.J., Brenner, K.P., Dufour, A.P., 2005. Comparison of Enterococcus measurements in freshwater at two recreational beaches by quantitative polymerase chain reaction and membrane filter culture analysis. Water Res. 39, 559-568.

Haugland, R.A., Siefring, S., Varma, M., Oshima, K.H., Sivaganesan, M., Cao, Y., et al., 2016. Multi-laboratory survey of qPCR enterococci analysis method performance in US coastal and inland surface waters. J. Microbiol. Methods 123, 114-125.

Hong, H., Qiu, J., Liang, Y., 2010. Environmental factors influencing the distribution of total and fecal coliform bacteria in six water storage reservoirs in the Pearl River Delta Region, China. J. Environ. Sci. 22, 663-668.

International Maritime Organization (IMO), 2004. International convention for the control and management of ships' ballast water and sediments. In: IMO BWM/CONF/36, 13 Feb 2004, London.

International Organization for Standardization (ISO) 7251, 1993. Microbiology-General Guidance for Enumeration of E. coli - Most Probable Number Technique.

Ishii, S., Ksoll, W.B., Hicks, R.E., Sadowsky, M.J., 2006. Presence and growth of naturalized Escherichia coli in temperate soils from Lake Superior watersheds. Appl. Environ. Microbiol. 72, 612-621.

Ishii, S., Hansen, D.L., Hicks, R.E., Sadowsky, M.J., 2007. Beach sand and sediments are temporal sinks and sources of Escherichia coli in Lake Superior. Environ. Sci. Technol. 41, 2203-2209.

Jeng, W.L., Han, B.C., 1994. Sedimentary coprostanol in Kaohsiung harbour and the Tan-Shui estuary, Taiwan. Mar. Pollut. Bull. 28, 494-499.

Kraus, R., Ninčević Gladan, Ž., Auriemma, R., Bastianini, M., Bolognini, L., Cabrini, M., Cara, M., Čalić, M., Campanelli, A., Cvitković, I., Despalatović, M., Drakulović, D., Flander-Putrle, V., Grati, F., Grego, M., Grilli, F., Jaklin, A., Janeković, I., Kolitari, J., Lipej, L., Magaletti, E., Marini, M., Mavrič, B., Mikuš, J., Mozetič, P., Orlando-Bonaca, M., Petović, S., Precali, R., Supić, N., Trabucco, B., Travizi, A., Žuljević, A. (a) Strategy of port baseline survey (PBS) in Adriatic Sea. Under review in Mar. Pollut. Bull. (same Special Issue).

Kraus, R., Grilli, F., Supić, N., Janeković, I., Brailo, M., Cara, M., Bratoš Cetinić, A., Campanelli, A., Cozzi, S., D'Adamo, R., Djakovac, T., Dutour-Sikirić, M., Flander-Putrle, V., France, J., Joksimović, D., Klun, K., Kolitari, J., Kralj, M., Kušpilić, G., Marini, M., Matić, F., Mikuš, J., Ninčević-Gladan, Ž., Pansera, M., Pećarević, M., Precali, R., Prusina, I., Relitti, F., Santucci, A., Specchiulli, A., Škalic, D. (b) Oceanographical characteristics of the Adriatic Sea - support to secondary spread of HAOP by natural dispersal. Under review in Mar. Pollut. Bull. (same Special Issue)
Laitano, M.V., Castro, Í.B., Costa, P.G., Fillmann, G., Cledón, M., 2015. Butyltin and PAH contamination of Mar del Plata port (Argentina) sediments and their influence on adjacent coastal regions. Bull. Environ. Contam. Toxicol. 95, 513-520.

Law, J.W.F., Ab Mutalib, N.S., Chan, K.G., Lee, L.H., 2015. Rapid methods for the detec tion of foodborne bacterial pathogens: principles, applications, advantages and limitations. Front. Microbiol. 5, 770.

Lee, C.M., Lin, T.Y., Lin, C.C., Kohbodi, G.A., Bhatt, A., Lee, R., Jay, J.A., 2006. Persistence of fecal indicator bacteria in Santa Monica Bay beach sediments. Water Res. 40 2593-2602.

Lin, Y.C., Chang-Chien, G.P., Chiang, P.C., Chen, W.H., Lin, Y.C., 2013. Multivariate analysis of heavy metal contaminations in seawater and sediments from a heavily industrialized harbor in southern Taiwan. Mar. Pollut. Bull. 76, 266-275.

Lipp, E.K., Kurz, R., Vincent, R., Rodriguez-Palacios, C., Farrah, S.R., Rose, J.B., 2001. The effects of seasonal variability and weather on microbial fecal pollution and enteric pathogens in a subtropical estuary. Estuaries 24, 266-276.

Luna, G.M., Vignaroli, C., Rinaldi, C., Pusceddu, A., Nicoletti, L., Gabellini, M., Danovaro, R., Biavasco, F., 2010. Extraintestinal Escherichia coli carrying virulence genes in coastal marine sediments. Appl. Environ. Microbiol. 76, 5659-5668.

Luna, G.M., Dell'Anno, A., Pietrangeli, B., Danovaro, R., 2012. A new molecular approach based on qPCR for the quantification of fecal bacteria in contaminated marine sediments. J. Biotechnol. 157, 446-453.

Lymperopoulou, D.S., Dobbs, F.C., 2017. Bacterial diversity in ships' ballast water, ballast-water exchange, and implications for ship-mediated dispersal of microorganisms. Environ. Sci. Technol. 51, 1962-1972.

McLellan, S.L., Eren, A.M., 2014. Discovering new indicators of fecal pollution. Trends Microbiol. 22, 697-706.

Newton, R.J., Bootsma, M.J., Morrison, H.G., Sogin, M.L., McLellan, S.L., 2013. A microbial signature approach to identify fecal pollution in the waters off an urbanized coast of Lake Michigan. Microb. Ecol. 65, 1011-1023.

Ng, C., Le, T.H., Goh, S.G., Liang, L., Kim, Y., Rose, J.B., Yew-Hoong, K.G., 2015. A comparison of microbial water quality and diversity for ballast and tropical harbor waters. PLoS One 10, e0143123.

Noble, R.T., Weisberg, S.B., 2005. A review of technologies for rapid detection of bacteria in recreational waters. J. Water Health 3, 381-392.

Noble, R.T., Lee, I.M., Schiff, K.C., 2004. Inactivation of indicator micro-organisms from various sources of faecal contamination in seawater and freshwater. J. Appl. Microbiol. 96, 464-472.

Noble, R.T., Blackwood, A.D., Griffith, J.F., McGee, C.D., Weisberg, S.B., 2010. Comparison of rapid quantitative PCR-based and conventional culture-based methods for enumeration of Enterococcus spp. and Escherichia coli in recreational waters. Appl. Environ. Microbiol. 76, 7437-7443.

Oberbeckmann, S., Fuchs, B.M., Meiners, M., Wichels, A., Wiltshire, K.H., Gerdts, G., 2012 Seasonal dynamics and modeling of a Vibrio community in coastal waters of the North Sea. Microb. Ecol. 63, 543-551.

Obiri-Danso, K., Jones, K., 1999. Distribution and seasonality of microbial indicators and thermophilic campylobacters in two freshwater bathing sites on the River Lune in northwest England. J. Appl. Microbiol. 87, 822-832.

Oliver, D.M., van Niekerk, M., Kay, D., Heathwaite, A.L., Porter, J., Fleming, L.E., Rahman, A., et al., 2014. Opportunities and limitations of molecular methods for quantifying microbial compliance parameters in EU bathing waters. Environ. Int. 64, 124-128.

Oliver, D.M., Hanley, N.D., van Niekerk, M., Kay, D., Heathwaite, A.L., Rabinovici, S.J., et al., 2016. Molecular tools for bathing water assessment in Europe: balancing social science research with a rapidly developing environmental science evidence-base. Ambio 45 (1), 52.

Oliver, D.M., Bird, C., Burd, E., Wyman, M., 2016. Quantitative PCR profiling of Escherichia coli in livestock feces reveals increased population resilience relative to culturable counts under temperature extremes. Environ. Sci. Technol. 50, 9497-9505.

Pachepsky, Y.A., Shelton, D.R., 2011. Escherichia coli and fecal coliforms in freshwater and estuarine sediments. Crit. Rev. Environ. Sci. Technol. 41, 1067-1110.

Pan, X., Jones, K.D., 2012. Seasonal variation of fecal indicator bacteria in storm events within the US stormwater database. Water Sci. Technol. 65, 1076-1080.

Penders, J., Vink, C., Driessen, C., London, N., Thiis, C., Sobberingh, E.E., 2005. Quantification of Bifidobacterium spp., Escherichia coli and Clostridium difficile in faecal samples of breast-fed and formula-fed infants by Real Time PCR. FEMS Microbiol. Ecol. 24, 141-147.

Perini, L., Quero, G.M., García, E.S., Luna, G.M., 2015. Distribution of Escherichia coli in a coastal lagoon (Venice, Italy): temporal patterns, genetic diversity and the role of tidal forcing. Water Res. 87, 155-165.

Quero, G.M., Fasolato, L., Vignaroli, C., Luna, G.M., 2015. Understanding the association of Escherichia coli with diverse macroalgae in the lagoon of Venice. Sci. Rep. 5 , 10969.

Renzi, M., Perra, G., Guerranti, C., Mariottini, M., Baroni, D., Volterrani, M., Graziosi, M., Specchiulli, A., Focardi, S., 2009. Assessment of environmental pollutants in ten southern Italy harbor sediments. Toxicol. Ind. Health 25, 351-363.

Shuval, H., 2003. Estimating the global burden of thalassogenic diseases: human infectious diseases caused by wastewater pollution of the marine environment. J. Water Health $1,53-64$.

Staley, J.T., Konopka, A., 1985. Measurement of in situ activities of non-photosynthetic microorganisms in aquatic and terrestrial habitats. Annu. Rev. Microbiol. 39, 321-346.

Stewart, J.R., Gast, R.J., Fujioka, R.S., Solo-Gabriele, H.M., Meschke, J.S., Amaral-Zettler, L.A., et al, 2008. The coastal environment and human health: microbial indicators, pathogens, sentinels and reservoirs. Environ. Health 7, S3. 
Viana, M., Hammingh, P., Colette, A., Querol, X., Degraeuwe, B., de Vlieger, I., van Aardenne, J., 2014. Impact of maritime transport emissions on coastal air quality in Europe. Atmos. Environ. 90, 96-105.

Vogel, L.J., Edge, T.A., O'Carroll, D.M., Solo-Gabriele, H.M., Robinson, C.E., 2017. Evaluation of methods to sample fecal indicator bacteria in foreshore sand and pore water at freshwater beaches. Water Res. 121, 204-212.

Wong, Y.S., Tam, N.F.Y., Lau, P.S., Xue, X.Z., 1995. The toxicity of marine sediments in Victoria Harbour, Hong Kong. Mar. Pollut. Bull. 31, 464-470.
Xu, W.Z., Cheung, S.G., Shin, P.K., 2014. Structure and taxonomic composition of free-living nematode and macrofaunal assemblages in a eutrophic subtropical harbour, Hong Kong. Mar. Pollut. Bull. 85, 764-773.

Zhang, L., Ye, X., Feng, H., Jing, Y., Ouyang, T., Yu, X., Liang, R., Gao, C., Chen, W., 2007. Heavy metal contamination in western Xiamen Bay sediments and its vicinity, China. Mar. Pollut. Bull. 54, 974-982.

Zhang, Q., He, X., Yan, T., 2015. Impact of indigenous microbiota of subtidal sand on fecal indicator bacteria decay in beach systems: a microcosm study. Environ. Sci. Water Res. Technol. 1, 306-315. 